\title{
BRONCHIOLITIS, RESPIRATORY SYNCYTIAL VIRUS, AND RECURRENT WHEEZING: WHAT IS THE RELATIONSHIP?
}

\author{
Claudia de Brito Fonseca and Sandra Grisi
}

\begin{abstract}
FONSECA C de B et al. - Bronchiolitis, respiratory syncytial virus, and recurrent wheezing: what is the relationship? Rev. Hosp. Clín. Fac. Med. S. Paulo 58(1):39-48, 2003.
\end{abstract}

Various follow-up studies of children hospitalized with bronchiolitis caused by respiratory syncytial virus have demonstrated that a significant proportion of infants (50\%) have recurrent wheezing during childhood. Nevertheless, the relationship between these two entities, if any, has not been established. In order to explain this observation, several hypotheses have been proposed. The first suggests that some children could have an individual predisposition to bronchiolitis caused by respiratory syncytial virus and recurrent wheezing. The virus could be a marker of this condition, and the individual predisposition could in turn be related to an individual hypersensitivity to common allergens (atopy), airway hyperreactivity, or to some disorder related to pulmonary anatomy or physiology that was present before the acute episode of bronchiolitis. Another hypothesis proposes that respiratory syncytial virus could be directly responsible for recurrent wheezing. During an episode of bronchiolitis, the damage in the airway mucosa caused by the vital inflammatory response to infection contributes to sensitivity to other allergens or exposes irritant receptors, resulting in recurrent wheezing. For this review, we analyzed the studies that discuss these hypotheses with the purpose of clarifying the mechanisms for the important issue of recurrent wheezing in childhood.

DESCRIPTORS: Respiratory Syncytial Virus. Respiratory Tract Infections. Acute Bronchiolitis. Recurrent Wheezing. Literature Review.

\section{INTRODUCTION}

Studies performed in children hospitalized with bronchiolitis due to respiratory syncytial virus (RSV) have shown that about $50 \%$ of these have episodes of recurrent wheezing. These episodes disappeared on average by 3 to 4 years of age ${ }^{1-7}$.

The high frequency with which such a clinical course occurs suggests that there is a relationship between the two phenomena. However, the nature of this relationship is not known. The question is whether RSV is responsible for this clinical course or is merely the marker of a predisposition to have wheezing crises.

The interest in clarifying this question lies in the possible therapeutic or prophylactic implications. If RSV bronchiolitis leads to the recurrent wheezing, this would justify research into the use of therapeutics that could decrease the inflammatory process and thereby contribute to the avoidance of subsequent wheezing. Studies that explore the use of corticoid therapy or sodium

From the Children's Institute, Hospital das Clínicas, Faculty of Medicine, University of São Paulo.

Received for publication on September 13, 2001. cromoglycate soon after the acute phase of bronchiolitis fall into this category ${ }^{8}$. On the other hand, if RSV can be used as a marker of children who will present recurrent wheezing, precocious identification of these patients would enable appropriate attendance and counseling. Many researchers have been working on this theme with the objective of identifying risk factors and decreasing morbidity.

The present work offers a review of the literature registered in Index Medicus and Latin-American Index Medicus over the last 25 years, through the databases of MEDLINE CD ROM and LILACS CD ROM. All 
of the studies published in English and Spanish were analyzed. The studies considered relevant for the analysis of bronchiolitis and recurrent wheezing involved children with confirmed infection due to RSV and without prior episodes of wheezing or any preexisting pathology. Therefore, those studies that evaluated the course of children presenting their first episode of wheezing without demonstration of the virus were excluded.

\section{RSV BRONCHIOLITIS AND RECURRENT WHEEZING}

The most significant works that evaluated sequels in children with RSV bronchiolitis are summarized in Table 1 . All of the studies were observational and had similar methodologies, in which hospitalized children were followed up or reevaluated with systematic research of the anomalies. The hospitalization criterion selected a population of more seriously ill patients with a greater possibility of sequels. In this context, it was demonstrated that $42 \%$ to $71 \%$ of the children admitted with RSV bronchiolitis experienced recurrent wheezing up to 6 to 10 years of age. Except for the work by Sims et al. ${ }^{1}$, the studies demonstrated alterations in pulmonary function tests that persisted many years after bronchiolitis, and the authors that researched bronchial lability after exercise or histamine/methacholine provocative testing also found an altered response in relation to the controls. None of the studies statistically analyzed the correlation of the occurrence of recurrent wheezing with the subgroup of the virus.

Regarding the cases of bronchiolitis that are not hospitalized, Stein et al. carried out a prospective study in which infants with disease of the lower respiratory tract before age 3 , due to various etiological agents, were followed up until age 13. The children infected with RSV had a 3 to 4 times greater chance of presenting recurrent wheezing by age 6 compared to the controls. Risk decreased markedly with age and was not significant by age 13. A similar tendency was observed in disease of the lower respiratory tract due to other agents (influenza, adenovirus, rhinovirus, cytomegalovirus, chlamydia, bacteria, and mixed infections), but this was less consistent than when due to RSV. A higher chance of recurrent wheezing was not detected among children with disease due to parainfluenza viruses ${ }^{9}$.

Consequently, the studies demonstrated that there is an association between RSV bronchiolitis and recurrent wheezing. This association does not depend on the gravity of the infection, since although more hospitalized children were studied, it was also demonstrated in patients treated in ambulatory settings. Hypotheses suggested to explain this association include:

1 - Severe respiratory infection - bronchiolitis as a clinical manifestation of RSV infection - occurs because the individual has a predisposition, which is responsible for the subsequent symptoms;

2 - The viral infection in an early phase of life causes damage to the immature lung or alters the immune response, thereby contributing directly to the recurrent wheezing.

In the first case, RSV bronchiolitis would be merely indicative of the preexisting condition; in the second case, there would be a cause and effect relationship. Still a third possibility would involve the sum of the above two factors.

\section{ANALYZING THE FIRST HYPOTHESIS}

Most infants are exposed to RSV and present an upper respiratory tract illness. However, approximately $25 \%$ to $40 \%$ of these infants present bronchiolitis $^{10}$. The following predisposing conditions could determine this difference in the response and also the development of recurrent wheezing:

1 - Hypersensitivity to common allergens (atopy);

2 - Airway hyperreactivity;

3 - Anatomic or physiological lung alterations.

\section{1 - Hypersensitivity to common allergens}

Atopy is a preexistent condition defined by hypersensitivity to common allergens; among other mechanisms, the individual presents an IgE-mediated response when in contact with certain agents ${ }^{11}$. This immune response could occur in response to the presence of the RSV itself, generating an airway inflammatory response, similar to that which occurs in asthma. Later, by virtue of the same predisposition, the individual presents wheezing crises when in contact with other agents.

\section{Type I hypersensitivity reaction in RSV bronchiolitis}

Type I hypersensitivity reaction classically occurs following the first contact with the antigen, with consequent production of specific $\operatorname{IgE}$ and few clinical manifestations. Thus, subsequent contact results in the inflammatory reaction, since the activation of mast cells and basophils by the IgE linked to the antigen leads to the release of mediators responsible for the inflammatory infiltrate, after which the symptoms become relevant ${ }^{11}$.

There is no epidemiological evidence of prior exposure to RSV among children with bronchiolitis ${ }^{12,13}$. However, in some cases during symptomatic infection, the production of RSV-specific IgE has been demonstrated, especially among infants with wheezing ${ }^{14,15-19}$.

Mast cell and basophil activation has been demonstrated through the 
Table 1 - Summary of the main findings from follow-up studies of children with bronchiolitis due to respiratory syncytial virus isolated in $100 \%$ of cases (all necessitated hospitalization).

\begin{tabular}{|c|c|c|c|c|c|}
\hline $\begin{array}{l}\text { Principal author, } \\
\text { Date }\end{array}$ & $\begin{array}{l}\text { Type of study } \\
\text { Number of patients } \\
\text { followed up }\end{array}$ & Parameters analyzed & Results & $\begin{array}{l}\text { Exposure to } \\
\text { cigarette smoke }\end{array}$ & $\begin{array}{l}\text { Correlation } \\
\text { with atopy }\end{array}$ \\
\hline Sims $^{1}, 1978$ & $\begin{array}{l}\text { Case-control } \\
35 \text { cases } \\
8 \text { years }\end{array}$ & $\begin{array}{l}\text { Wheezing } \\
\text { PFT } \\
\begin{array}{l}\text { Bronchial lability } \\
\text { after exercise }\end{array}\end{array}$ & $\begin{array}{l}50 \% \text { in cases } \\
3 \% \text { controls } \\
\text { NS } \\
\text { Greater than } \\
\text { in controls }\end{array}$ & NS & NS \\
\hline Pullan $^{2}, 1982$ & $\begin{array}{l}\text { Case-control } \\
130 \text { cases } \\
10 \text { years }\end{array}$ & $\begin{array}{l}\text { Wheezing } \\
\text { PFT } \\
\begin{array}{l}\text { Lability after } \\
\text { exercise } \\
\text { Histamine } \\
\text { provocative testing }\end{array}\end{array}$ & $\begin{array}{l}42 \% \text { cases and } \\
19 \% \text { of controls } \\
\text { Altered in } \\
\text { all indices } \\
16 \% \text { of cases } \\
5 \% \text { controls } \\
19 \% \text { of cases } \\
7 \% \text { controls } \\
\end{array}$ & $\begin{array}{l}\text { Greater exposure } \\
\text { in cases compared } \\
\text { to control group }\end{array}$ & NS \\
\hline Hall $^{3}, 1984$ & $\begin{array}{l}\text { Prospective } \\
25 \text { cases } \\
8 \text { years }\end{array}$ & $\begin{array}{l}\text { Wheezing } \\
\text { PFT }\end{array}$ & $\begin{array}{l}45 \% \text { after } 4 \text { years } \\
\text { and } 20 \% \text { after } \\
8 \text { years } \\
\text { FEV1/FVC and } \\
\text { PEFR normal } \\
\downarrow \text { FEF } 25-75 \text { and } \\
\text { Vmax } 25\end{array}$ & $76 \%$ of cases & NS \\
\hline $\mathrm{Sly}^{4}, 1989$ & $\begin{array}{l}\text { Prospective } \\
35 \text { cases } \\
6 \text { years }\end{array}$ & $\begin{array}{l}\text { Wheezing } \\
\text { Spirometry } \\
\text { Histamine } \\
\text { provocative testing }\end{array}$ & $\begin{array}{l}71 \% \text { of cases } \\
\frac{\downarrow \text { in } 12 \% \text { of cases }}{84 \% \text { of cases }}\end{array}$ & $86 \%$ of cases & NA \\
\hline $\begin{array}{l}\text { Welliver } 5,6 \\
1993\end{array}$ & $\begin{array}{l}\text { Prospective } \\
43 \text { cases } \\
7-8 \text { years }\end{array}$ & $\begin{array}{l}\text { PFT } \\
\\
\text { Methacoline } \\
\text { provocative testing }\end{array}$ & $\begin{array}{l}60 \% \text { in } 5 \text { years } \\
30 \% \text { in } 8 \text { years } \\
\text { FEF } 25-75 \\
\text { and FEF50 } \\
60 \% \text { to } 80 \% \text { of } \\
\text { the expected values } \\
70 \% \text { of cases and } \\
11 \% \text { of controls } \\
\end{array}$ & $\begin{array}{l}\text { Correlated with } \\
\text { reduced small } \\
\text { airway function }\end{array}$ & $\begin{array}{l}\text { Correlated with } \\
\text { reduced large } \\
\text { airway function }\end{array}$ \\
\hline Sigurs ${ }^{7}, 1995$ & $\begin{array}{l}\text { Prospective, } \\
\text { case-control } \\
47 \text { cases } \\
3 \text { years }\end{array}$ & Wheezing & $\begin{array}{l}60 \% \text { of cases } \\
32 \% \text { of controls }\end{array}$ & NS & $\begin{array}{l}32 \% \text { of cases } \\
9 \% \text { of controls }\end{array}$ \\
\hline
\end{tabular}

products they release: histamine in the nasopharyngeal secretions of the infants infected by $\mathrm{RSV}^{17,20}$ and tryptase concentration (a mast cell-specific product), in bronchoalveolar lavage ${ }^{21}$. In addition, leukotriene C-4 $\left(\mathrm{LTC}_{4}\right)$ was found more frequently in the nasopharyngeal secretion of children with wheezing, and the concentrations were 5-fold higher than in children with upper airway illness. Leukotriene C-4 is a potent bronchoconstrictor and inductor of mucus secretion, and in addition, produces an increase in vascular permeability and induces pulmonary edema ${ }^{22}$. Leukotriene C-4 was detected in $83 \%$ of the children with RSV-specific IgE in the nasopharynx and $24 \%$ of the children without RSVspecific $\operatorname{IgE}(P<0.001)^{23}$.

Among the mediators released by the mast cells and basophils are eosinophil chemotactic factors. The presence of eosinophils in the lower air- ways during RSV infection is not well clarified, but the eosinophilic cationic protein $(\mathrm{ECP})$ concentration that is released by them indirectly indicates their participation. Eosinophilic cationic protein concentration in children with RSV bronchiolitis was significantly higher than the ECP concentration in both groups of children with RSV upper respiratory illness and groups with RSV pneumonia without wheezing ${ }^{24}$. 
In short, there is evidence that an IgE-mediated reaction occurs in RSV infections, including detection of RSV-specific IgE in the nasopharynx of $50 \%$ to $65 \%$ of patients and indirect data indicating the participation of basophils, mast cells, and eosinophils, namely the concentrations of histamine, tryptase, and mediators such as $\mathrm{LTC}_{4}$ and ECP. These elements in general have a higher presence in wheezing illness, and some are linked to greater gravity. Infants with pneumonia without wheezing and who also have an intense inflammatory process present smaller amounts of IgE and histamine than children with wheezing, indicating that the greater quantity of these factors is not related to the degree of inflammation alone, but are in fact a component of hypersensitivity ${ }^{14,17,21,23,24}$.

Not all of the episodes of bronchiolitis are accompanied by detection of these factors. This could be due to technical difficulties or to participation of this reaction only in predisposed individuals. It should be remembered that IgE-mediated hypersensitivity reaction is not the only pathogenetic mechanism of bronchiolitis. Hence, there are other factors involved in its pathogenesis ${ }^{25}$.

\section{The relationship between RSV bron- chiolitis and atopy}

Demonstration of atopy among infants with RSV bronchiolitis would reveal a preexistent condition responsible for the bronchiolitis and recurrent wheezing. The presence of manifestations such as allergic rhinitis, atopic dermatitis, and asthma, in addition to sensitization against common environmental antigens and eosinophilia, are found in atopic individuals ${ }^{11}$. These phenomena have been investigated in children with RSV bronchiolitis.

The findings of the various studies on this theme are controversial (Table 1). In general, an association has not been confirmed between RSV bronchiolitis and the presence of atopy; in other words, it seems that atopy is not a predisposing condition for the development of bronchiolitis ${ }^{2,3,7}$. With regard to recurrent wheezing, in a longitudinal study, Stein et al. demonstrated that the association between RSV and increased risk of recurrent wheezing was independent of an allergic sensitization ${ }^{9}$.

However, in other studies, atopic children apparently had a higher chance of experiencing recurrent wheezing following RSV bronchiolitis than nonatopic children ${ }^{1,26}$. Based on this, some authors have tried to identify a marker related to atopy that appears during bronchiolitis and that can predict which children will develop recurrent wheezing. The researchers measured RSV-specific IgE, number of eosinophils in the acute phase of the disease, ECP in nasal secretions, and myeloperoxidase, and then correlated these with the clinical course $5,27,28,29$. However, to date, no study has been conclusive. Nevertheless, there are indications that RSVspecific IgE could be this marker. Welliver et al. have demonstrated that infants with high levels of RSV-specific IgE at the time of the RSV infection present a $70 \%$ chance of recurrent wheezing by age 4 and that undetectable RSV-specific IgE is associated with a $80 \%$ chance of no recurrence ${ }^{5}$. Eosinophilia during the acute phase of the infection, although it has low sensitivity $(27 \%)$, demonstrated a specificity of $75 \%$ to $94 \%$ in predicting recurrent wheezing ${ }^{27,28}$.

\section{2 - Airway hyperreactivity}

Another preexistent condition is related to the airway hyperreactivity to nonspecific stimulus. This hyperreactivity is demonstrated through alterations in pulmonary function testing after inhalation of substances such as methacholine, histamine, and cold air or stimuli such as physical exercise $^{30-32}$. This reactivity appears to decrease with age, such that the histamine or methacholine doses necessary to produce a bronchial provocation tests response in children are many times smaller than those necessary to stimulate adults ${ }^{33}$. Likewise, normal adults do not present alteration in pulmonary function after cold air inhalation. It is speculated that underlying enhanced airway reactivity is present in some children from birth and that loss of reactivity is part of the normal development and lung maturation process $^{34}$.

Once RSV involves the infant's lungs, a marked reactivity could be triggered, thereby explaining the occurrence of bronchiolitis. Other common viral infections in this phase of life could lead to subsequent wheezing until lung maturation is reached and the reactivity decreases. At present, this is just a hypothesis, since there are no studies demonstrating that infants with RSV bronchiolitis had airway hyperreactivity prior to the episode. All of the studies found alterations in the bronchial provocation tests after bronchiolitis (Table 1).

\section{3 - Anatomic physiological lung al- teration}

Finally, some anatomic physiological airway alterations, such as narrowing for instance, could lead to diminished lung function, which though without clinical manifestation, could mean that the individual is at increased risk for obstruction with viral infections. These would be "transitory wheezers" in which recurrent wheezing would cease by age 4 to 5 years, as their airways increase in size or as airway-parenchymal interactions change $^{34}$. This possibility is strongly supported by Martinez et al. who performed pulmonary function testing on 124 children before 6 months of age before any lower respiratory tract ill- 
ness had developed. They then followed these infants through the first year of life and studied the incidence and characteristics of lower respiratory tract illness among them. In the case of boys, the lower conductance values corresponded to a 10 -fold greater chance of presenting wheezing compared to infants with higher values. This alteration could reflect narrower airways. For girls, the higher risk of wheezing (16-fold greater chance) was linked to a decrease in the functional residual capacity (FRC), reflecting a smaller size of the lungs ${ }^{35}$. Therefore, children of both sexes can be predisposed to wheezing, but due to different aspects of the pulmonary function.

A study has yet to be performed using appropriate specific methodology for children with RSV bronchiolitis and measurement of prior lung function.

\section{ANALYZING THE SECOND HYPOTHESIS}

The possibility that RSV infection causes recurrent wheezing would have the following mechanism: during a bronchiolitis episode, damage to the respiratory mucosa due to the intense inflammatory process, especially in the most severe disease, would facilitate sensitization by other allergens or would provoke an exposure of irritant receptors, resulting in the recurrent wheezing ${ }^{36}$.

The available studies were performed in experimental models or in vitro using human lymphocytes. Regarding the favoring or accentuation of atopy, it was demonstrated that animals infected with RSV present greater sensitization when exposed to allergens such as pollen and ovalbumin than noninfected animals. Similarly, while studying lymphocytes of infants after RSV infection, greater sensitization was demonstrated against Dermatophagoides farinae, $\alpha$-casein, and ovalbumin compared to a group that suffered infection due to other agents $^{37-40}$.

Experimental models have also demonstrated that there is induction of airway hyperreactivity to provocation testing after RSV bronchiolitis, which can normalize with time ${ }^{41,42}$. The virus causes acute and chronic changes in neural control of airways in animal models. Specifically, after experimental RSV infection, there is an increase in the contraction mediated by the cholinergic and nonadrenergic, noncholinergic excitatory (NANCe) pathway, as well as a decrease in bronchodilation mediated by a nonadrenergic, noncholinergic inhibitory (NANCi) pathway ${ }^{43}$.

Furthermore, there appears to be an interaction between the sensitization and the hyperreactivity after RSV bronchiolitis. Animals sensitized by ovalbumin inhalation prior to RSV infection present an increase in the pulmonary resistance to provocation testing with acetylcholine on day 6 of the infection and markedly greater histological pulmonary damage than animals that had RSV infection alone or were only sensitized to ovalbumin ${ }^{44}$. It has been suggested that a preexistent allergic state can lead to hyperreactivity that is associated with greater epithelial damage during RSV infection ${ }^{45}$.

These studies suggest that RSV bronchiolitis can favor sensitization against other allergens. But it still has not been possible to establish a relationship between these experiments and clinical findings. As mentioned above, we did not find a constantly greater incidence of atopy among the children that had bronchiolitis. Maybe this mechanism is important in producing an enhancement of the atopy in atopic children, but it does not seem that the RSV itself induces the atopy. On the other hand, there is better correlation of experimental and clinical studies regarding the hyperreactivity after bronchiolitis, because this is verified in many children who had bronchiolitis. It is possible that the viral infection can only delay pulmonary maturation in terms of the improvement in the airway reactivity with the age, since the risk of wheezing decreases markedly during childhood ${ }^{9,34}$.

Whatever the case, it is difficult to interpret the relationship between an event that occurred in infancy and alterations demonstrated years later. Many other factors can interfere in pulmonary function over time, such as pollution, exposure to cigarette smoke and other irritants, or sensitization to various allergens that are not always detected by the common tests ${ }^{3,46,47}$. As summarized in table 1 , exposure to cigarette smoke was greater in the bronchiolitis cases than among the controls, thereby constituting a confusing factor in the interpretation of the relationship between RSV bronchiolitis and recurrent wheezing. The recurrence of the inflammatory process itself, whatever the triggering factor, can contribute to the alteration of pulmonary function.

\section{CONCLUSIONS}

- Children hospitalized for RSV bronchiolitis have, on average, a 50\% chance of presenting recurrent wheezing. Therefore, families should be counseled regarding the possibility of undergoing a special follow-up. Since symptoms tend to disappear with time, excessive diagnostic investigations are unnecessary.

- Recurrent wheezing in the child with RSV bronchiolitis can be related to factors present prior to the bronchiolitis, such as atopy, airway hyperreactivity, or an anatomic physiological alteration of the airways (less conductance or lower functional residual capacity (FRC)). Furthermore, experimental studies suggest that 
lower-airway damage provoked by RSV can alter the course of bronchial hyperreactivity and enhance atopy, thereby enabling the sensitization against other allergens or alteration of the pulmonary function.

- Both these hypotheses that have been presented to explain the relationship between RSV bronchiolitis and recurrent wheezing are possible. The most probable is that there are different groups of children in which each of the alterations may be present, including an interrelationship between them. The effects caused by the virus would be dependent on each of the conditions presented by the host. Manifestation of these alterations can also be related to exposure to environmental factors. The following figure summarizes these possibilities.

\section{PERSPECTIVES}

The pathogenesis of bronchiolitis is not fully understood. This review concentrated on those aspects related to IgE-mediated immunity because their relationship with recurrent wheezing has been studied most. As already mentioned, the determination of a marker that appears during bronchiolitis and that could be predictive of which children will present recurrent wheezing would be very useful during the follow up of these patients. Researchers have been working in this area, and the results regarding RSVspecific IgE are promising.

Within the same field, the use of corticoids for the treatment of bronchiolitis or recurrent wheezing prevention is frequently studied. However, the use of corticoids remains controversial, and the conflicting results are mainly due to inadequate methodology of the studies $^{8}$. It is possible that this therapeutic approach would be beneficial for a specific group of children that react with production of RSV-specific IgE. To confirm this possibility, case-control studies would be necessary in children with RSV bronchiolitis without chronic disease or previous wheezing, identifying those who produce RSV-specific IgE or not and selecting them to receive or not receive corticoid therapy during and after bronchiolitis. These patients would then have to be followed up prospectively to determine the risk of presenting recurrent wheezing.

Regarding other aspects of the humoral immunity, it is known that although infection by RSV does not induce definitive immunity, high titers of RSV- specific IgG protect against the occurrence of bronchiolitis by restricting the infection to the upper air-

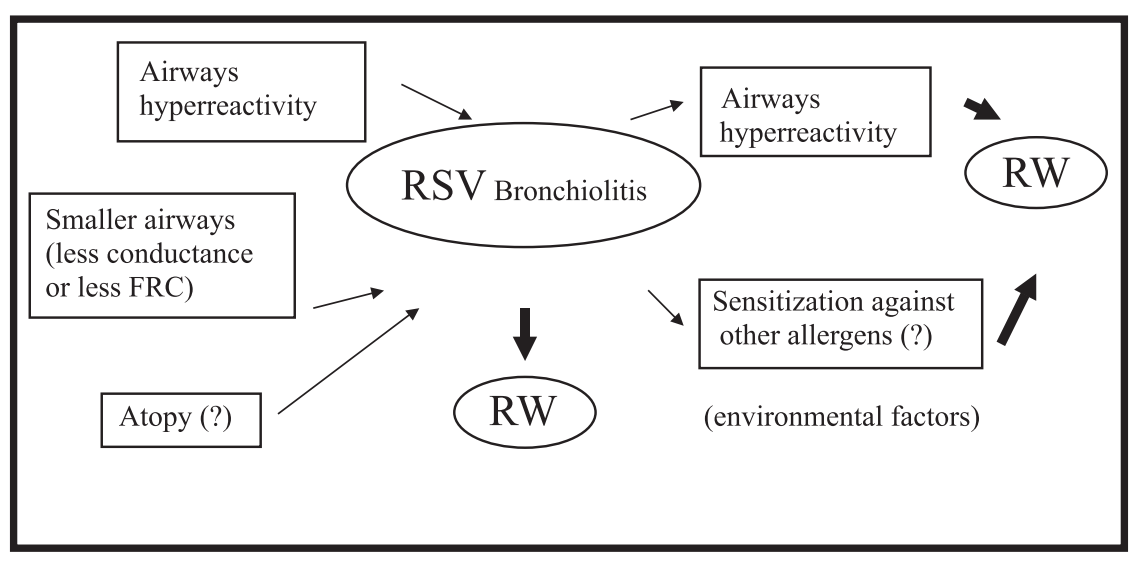

Figure 1 - Respiratory syncytial virus bronchiolitis and recurrent wheezing. RSV: Respiratory syncytial virus; RW: Recurrent wheezing; FRC: Functional residual capacity. ways. Thus, the use of gamma-globulin for the prophylaxis of bronchiolitis, although not in current use primarily because of its high cost, would contribute to avoiding the occurrence of recurrent wheezing. Its use at present is restricted to children with risk factors for severe disease due to RSV. There are no studies regarding the impact of this management in the infant population in general. Likewise, the production of a vaccine that stimulates the production of antibodies could also contribute to prophylaxys ${ }^{25}$.

With regard to cellular immunity, although this is the main factor responsible for viral clearance, its activation between 5 and 7 day of the disease coincides with the worsening of the symptoms. In other words, the lymphocytes responsible for eliminating the virus can contribute to the damage of the respiratory mucosa. Before interfering with the cellular immunity process, more study is needed to understand and evaluate the delicate balance between protection and damage production ${ }^{25}$.

The treatment of bronchiolitis with ribavirin has been analyzed as an intervention that can reduce the chance of recurrent wheezing. However, as yet there has been no conclusive study, the question remains controversial ${ }^{48,49}$.

Finally, attempts to classify children according to progression of the wheezing and its pathophysiological condition facilitate an understanding of the morbid process and allow for better management and potentially for reduced morbidity. This is one of the objectives of research that is dedicated to the study of bronchial asthma. It has been suggested that there are 3 distinct phenotypes among wheezing infants, reflecting a heterogeneous group of conditions, whose common final pathway is recurrent airway obstruction: (1) "transient early wheezing" in which the associated condition would be a reduced pulmonary function that 
resolves by age 3 ; (2) "nonatopic wheezing" characterized by disappearance of the symptoms by age 13 and nonallergic sensitization, with viral infection as the common cause of obstruction of the airways, especially due to RSV; and (3) "atopic wheezing/ asthma" that progresses with the classic form of persistent asthma. These groups were defined in longitudinal studies, after many years of follow-up of wheezing children ${ }^{50}$.

How to determine prospectively which group each child will belong to after RSV bronchiolitis remains to be discovered. Furthermore, it is necessary to continue this follow-up and to review this classification, since even those individuals that improve with age can become symptomatic in adult life ${ }^{42}$.

\section{ACKNOWLEDGMENTS}

The authors extend their thanks to Dr. Joaquim Carlos Rodrigues for his criticism and suggestions.

\section{RESUMO}

FONSECA C de B e col. - A bronquiolite pelo virus sincicial respiratório e o chiado recorrente: qual a relação? Rev. Hosp. Clín. Fac. Med. S. Paulo 58(1):39-48, 2003.

Os diversos estudos de seguimento de crianças hospitalizadas por bronquiolite pelo virus sincicial respiratório demonstram, em média, 50\% de chance de evoluir com novos episódios de chiado no peito. Apesar desta constatação, não foi estabelecida a relação entre a bronquiolite pelo virus sincicial respiratório e a recorrência dos episódios de chiado. A primeira hipótese é de que o indivíduo poderia ter uma predisposição para a repetição do quadro de chiado e também para a própria bronquiolite como manifesta- ção da infecção pelo virus sincicial respiratório. $\mathrm{O}$ vírus seria um marcador desta condição. Esta predisposição pode estar relacionada a uma hipersensibilidade a alérgenos comuns (atopia), hiper-reatividade a estímulos não específicos ou alguma alteração pulmonar anátomo-fisiológica presentes antes da bronquiolite.

Outra hipótese é a de que o virus 
sincicial respiratório é o responsável por esta evolução. Durante um episódio de bronquiolite, a lesão da mucosa respiratória decorrente do intenso processo inflamatório, principalmente nos quadros mais graves, facilitaria a sensibilização para outros alérgenos ou provocaria uma exposição de recep- tores para irritantes, resultando nos quadros de chiado recorrentes.

Nesta revisão, os autores analisam as pesquisas que sustentam essas hipóteses com o objetivo de sistematizar o conhecimento sobre este assunto e apresentá-lo de forma organizada, como uma contribuição à compreensão da recorrência dos episódios de chiado.

DESCRITORES: Vírus sincicial respiratório. Infecções respiratórias. Bronquiolite aguda. Chiado recorrente. Revisão da literatura.

\section{REFERENCES}

1. SIMS DG, DOWNHAM MAPS, GARDNER PS et al. - Study of 8-year-old children with a history of respiratory syncytial virus bronchiolitis in infancy. Brit Med J 1978; 1:11-4.

2. PULLAN CR, HEY EN - Wheezing, asthma, and pulmonary dysfunction 10 years after infection with respiratory syncytial virus in infancy. Brit Med J 1982; 284: 1665-9.

3. HALL CB, HALL WJ, GALA CL,MAGILL FB, LEDDY JP Long-term prospective study in children after respiratory syncytial virus infection. J Pediatr 1984; 105: 358-64.

4. SLY PD, HIBBERT ME - Childhood asthma following hospitalization with acute viral bronchiolitis in infancy. Pediatr Pulmonol 1987; 7: 153-8.

5. WELLIVER RC, SUN M, RINALDO D et al. - Predictive value of respiratory syncytial virus-specific IgE responses for recurrent wheezing following bronchiolitis. J Pediatr 1986; 109: 77680 .

6. WELLIVER RC,DUFFY L - The relationship of RSV-specific immunoglobulin $\mathrm{E}$ antibody responses in infancy, recurrent wheezing, and pulmonary function at age 7-8 years. Pediatr Pulmonol 1993; 15: 19-27.
7. SIGURS N, BJARNASON R, SIGURBERGSSON F et al. - Asthma and immunoglobulin $\mathrm{E}$ antibodies after respiratory syncytial virus bronchiolitis: a prospective cohort study with matched controls. Pediatrics 1995;95: 500-5.

8. FOX GF,EVERARD ML,MARSH M et al-Randomised controlled trial of budesonide for the prevention of post-bronchiolitis wheezing. Arch Dis Child 1999; 80: 343-7.

9. STEIN RT, SHERRIL D,MORGAN WJ et al. - Respiratory syncytial virus in early life and risk of wheeze and allergy by age 13 years. Lancet 1999;354: 541-45.

10. LARRAÑAGA C,AVENDANO L - Infección por virus sincicial respiratorio humano. Rev Chil Infectol 1990;7:189-95.

11. PEARLMAN DS, BIERMAN CW - Allergic disorders. In: STIEHM ER - Immunologic Disorders in Infants \& Children Philadelphia, Saunders, 1996. p. 603-43.

12. McINTOSH K - Bronchiolitis and asthma: possible common pathogenic pathways. J Allergy Clin Immunol 1975; 57: 595604. 
13. McINTOSH K, FISHAUT JM - Immunopathologic mechanism in lower respiratory tract disease of infants due respiratory syncytial virus. Prog Med Virol 1980; 26: 94-118.

14. BUI RHD ,MOLINARO GA, KETTERING JD et al. - Virus-specific IgE and IgG4 antibodies in serum of children infected with respiratory syncytial virus. J Pediatr 1987; 110: 87-90.

15. RUSSI JC, DELFRARO A, BORTHAGARAY MD et al. Evaluation of immunoglobulin E-specific antibodies and viral antigens in nasopharyngeal secretions of children with respiratory syncytial virus infection. J Clin Microbiol 1993; 31: 819-23.

16. TOMS GL, QUINN R, ROBINSON JW - Undetectable IgE responses after respiratory syncytial virus infection. Arch Dis Child 1996; 74: 126-30.

17. WELLIVER RC, WONG DT, SUN M et al. - The development of respiratory syncytial virus-specific $\operatorname{IgE}$ and the release of histamine in nasopharyngeal secretions after infection. $\mathbf{N}$ Engl J Med 1981; 305: 841-6.

18. WELLIVER RC, SUN M, RINALDO D,OGRA PL - Respiratory syncytial virus-specific IgE responses following infection: evidence for a predominantly mucosal response. Pediatr Res 1985; 19: 420-4

19. WELLIVER RC, SUN M, HILDRETH SW et al. - Respiratory syncytial virus-specific antibody responses in immunoglobulin $\mathrm{A}$ and $\mathrm{E}$ isotypes to the $\mathrm{F}$ and $\mathrm{G}$ proteins and to intact virus after natural infection. J Clin Microbiol 1989; 27: 295- 9.

20. CASWELL SJ, THOMSON AH, ASHMORE SP et al. - Latent sensitization to respiratory syncytial virus during acute bronchiolitis and lung function after recovery. Arch Dis Child 1990; 65: 946-52.

21. EVERARD ML, FOX G, WALLS AF et al. - Tryptase and IgE concentrations in the respiratory tract of infants with acute bronchiolitis. Arch Dis Child 1995; 72: 64-9.

22. VOLOVITZ B, FADEN H,OGRA PL - Release of leukotriene C4 in respiratory tract during acute viral infection. J Pediatr 1988; 112: 218-22.

23. VOLOVITZ B, WELLIVER RC, CASTRO G et al. - The release of leukotrienes in the respiratory tract during infection with respiratory syncytial virus: role in obstructive airway disease. Pediatr Res 1988; 24: 504-7.

24. GAROFALO R, KIMPEN JLL, WELLIVER RC et al. - Eosinophil degranulation in the respiratory tract during naturally acquired respiratory syncytial virus infection. J Pediatr 1992; 120: $28-32$.

25. FONSECA CB - Aspectos imunológicos das infecções agudas pelo vírus sincicial respiratório em lactentes. São Paulo, 1998. (Dissertação (mestrado) - Faculdade de Medicina da Universidade de São Paulo).

26. SIMS DG, GARDNER PS, WEIGHTMAN D et al. - Atopy does not predispose to RSV bronchiolitis or postbronchiolitic wheezing. Brit Med J 1981; 282: 2086-8.

27. EHLENFIELD DR, CAMERON K, WELLIVER RC - Eosinophilia at the time of respiratory syncytial virus bronchiolitis predicts childhood reactive airway disease. Pediatrics 2000; 105: 79-83.
28. MARTINEZ FD, STERN DA, WRIGHT AL et al. - Differential immune responses to acute lower respiratory illness in early life and subsequent development of persistent wheezing and asthma. J Allergy Clin Immunol 1998; 102: 915-20.

29. SIGURS N, BJARNASON R,SIGURBERGSSON F - Eosinophil cationic protein in nasal secretion and in serum and myeloperoxidase in serum in respiratory syncytial virus bronchiolitis: relation to asthma and atopy. Acta Paediatr 1994; 83: 1151-5

30. TEPPER RS - Airway reactivity in infants: a positive response to methacholine and metaproterenol. Appl Physiol 1987; 62(3): $1155-9$.

31. LESOUËF PN, GEELHOED GC, TURNER DJ et al. - Response of normal infants to inhaled histamine. Am Rev Respir Dis 1989; 139: 62-6.

32. GELLER DE, MORGAN WJ, COTA KA et al. - Airway responsiveness to cold, dry air in normal infants. Pediatr pulmonol 1988; 4: 90-7.

33. MONTGOMERY GL, TEPPER RS - Changes in airway reactivity with age in normal infants and young children. Am Rev Respir Dis 1990; 142:1372-76.

34. TAUSSIG LM - The conundrum of wheezing and airway hyperreactivity in infancy. Pediatr Pulmonol 1992; 13:1-3.

35. MARTINEZ FD,MORGAN WJ, WRIGHT AL et al. - Diminished lung function as a predisposing factor for wheezing respiratory illness in infants. N Engl J Med 1988; 319: 1112-7.

36. FOLKERTS G, NIJKAMP FP - Virus-induced airway hyperresponsiviness - role of inflammatory cells and mediators. Am J Respir Crit Care Med 1995; 151: 1666-74.

37. FREIHOSRT J,PIEDRA PA,OKAMOTO Y et al. - Effect of respiratory syncytial virus infection on the uptake of and immune response to other inhaled antigens. Proc Soc Exp Biol Med 1988; 188: 191-7.

38. LEIBOVITZ E, FREIHORST J, PIEDRA PA et al. - Modulation of systemic and mucosal immune responses to inhaled ragweed antigen experimentally induced infection with respiratorysyncytial virus implication in virally induced allergy. Int Arch Allergen Appl Immun 1988; 86: 112-6.

39. DAKHAMA A, BRAMLEY AM, CHAN NG et al. - Effect of respiratory syncytial virus on subsequent allergic sensitization to ovalbumin in guinea-pigs. Eur Respir J 1999; 13: 976-82.

40. NOMA T, MORI A, YOSHIZAWA I - Induction of allergenspecific IL-2 responsiveness of lymphocytes after respiratory syncytial virus infection and prediction of onset of recurrent wheezing and bronchial asthma. J Allergy Clin Immunol 1996; 98: $1-26$.

41. BRAMLEY AM, VITALIS TZ, WIGGS BR et al. - Effects of respiratory syncytial virus persistence on airway responsiveness and inflammation in guinea-pigs. Eur Respirar J 1999; 14: 1061-67.

42. HOGG JC - Childhood viral infection and the pathogenesis of asthma and chronic obstructive lung disease. Am J Respir Crit Care Med 1999;160: S26-8. 
Bronchiolitis, respiratory syncytial virus, and recurrent wheezing Fonseca $\mathrm{C}$ de $\mathrm{B}$ et al.

43. LARSEN GL, COLASURDO GN - Neural control mechanisms within airways: Disruption by respiratory syncytial virus. J Pediatr 1999; 135: S21-S27.

44. SCHWARZE J, HAMELMANN E, BRADLEY KL et al. Respiratory syncytial virus infections results in airway hyperresponsiveness and enhanced airway sensitization to allergen. J Clin Invest 1997; 100: 226-3.

45. ROBINSON PJ, HEGELE RG, SCHELLENBERG RR - Allergic sensitization increases airway reactivity in guinea pigs with respiratory syncytial virus bronchiolitis. J Allergy Clin Immunol 1997; 100: 492-8.

46. CELEDON JC,LitONJUA A.A, WEISS ST et al. - Day care attendance in the first year of life and illnesses of the upper and lower respiratory tract in children with a familial history of atopy. Pediatrics 1999; 104:495-500.
REV. HOSP. CLÍN. FAC. MED. S. PAULO 58(1):39-48, 2003

47. KATTAN M - Epidemiologic evidence of increased airway reactivity in children with a history of bronchiolitis. J Pediatr 1999; 135: S8-13.

48. EDELL D, BRUCE E, HALE K et al. - Reduced long-term respiratory morbidity after treatment of Respiratory Syncytial Virus bronchiolitis with ribavirin in previously healthy infants: a preliminary report. Ped Pulmonol 1998; 25:154-8.

49. McBRIDE JT, McCONNOCHIE KM - Respiratory syncytial virus, recurrent wheezing and ribavirin. Ped Pulmonol 1998; 25:145-6.

50. MARTINEZ FD - Development of wheezing disorders and asthma in preschool children. Pediatrics 2002; 109: 362-7. 